\title{
THE VISION OF THE EDUCATIONAL PROCESS IN POLISH AND UKRAINIAN CORE CIRRICULA. ANALYSIS BASED ON THE HOFSTEDE 4-D MODEL
}

\author{
ANZHELA POPYK ${ }^{1} \&$ ANNA PERKOWSKA-KLEJMAN ${ }^{2}$ \\ ${ }^{1}$ SWPS University of Social Sciences and Humanities, Chodakowska 19/31 Street, 03-815, Warsaw, Po- \\ land. ORCID: 0000-0003-4627-3517,Email: angelikapopyk@gmail.com \\ ${ }^{2}$ The Maria Grzegorzewska University, Social Pedagogy Department, Szczęśliwicka 40 Street, 02-353 \\ Warsaw, Poland. ORCID: 0000-0003-4601-9877, Email: aperkowska@aps.edu.pl
}

ABSTRACT: National curricula are documents describing the knowledge, skills and social competences that students should acquire at the appropriate stages of education. In our article, we assume that these documents have the power to buttress the existing status quo or to change reality. Generally speaking, they are an attempt at transforming selected areas of culture in a deliberate, planned, and systemic manner.

This paper, by means of Hofstede's 4-D model of cultural differences among societies (viz power distance, uncertainty avoidance, individualism versus collectivism, masculinity versus femininity), is aimed at studying the way Polish and Ukrainian national curricula define the educational processes and Teacher-Student relations, in order to reveal the correlation between the cultural differences and learning/teaching process in Poland and Ukraine. A critical discourse analysis of the two state curricula has been done to interpret their contents.

KEYWORDS: educational process, teacher-student relations, cultural dimensions, discourse analyses, core curriculum 


\section{INTRODUCTION}

Education is the basis of the intellectual, spiritual, physical and cultural development of an individual, their successful socialization, economic well-being, key to the development of a society, united by shared values and culture, and the state (Ukraine, Law “On Education” 2017).

The plot of the world-famous Houellebecq (2016) novel Submission (French: Soumission) takes place in a fictitious space and presents a vision of the future, but selected elements of the reality contained therein could happen. It is 2022. The Muslim Brotherhood wins the elections. The winning party is particularly interested in that area of state apparatus which is education. Controlling this ministry, controlling schools and colleges and dictating the content of the national curriculum allows for the rapid implementation of major social changes.

Education is an integrative part of the development of every child in the majority of countries. Primary and secondary education are compulsory till the age of 18 in both Poland and Ukraine (Ukraine, Law "On Education" 2017, Art. 12, Poland, The Law on School 2016, Art. 31). Education is the "state priority that provides innovative, socio-economic and cultural development of society" (Ukraine, Law "On Education" 2017, Art. 5). The central requirements concerning the education process in a country is determined by law at a national level, whilst the specific conditions of learning and teaching are presented in other regulations. In Ukraine, the educational process is defined by the Decree "The State Standards for Primary Education" (2011) and "The State Standards for Basic and Complete Secondary Education" (2011); in Poland its defined by the Regulation of the Minister of National Education of Poland of 14 February 2017 on the core curriculum for pre-school education and the core curriculum for general education in primary schools.

One of the key purposes of students' learning is to educate and carry the national, historical and cultural values of the country (Ukraine, Law “On Education” 2017, Art. 54. Poland, The Law on School 2016). On the other hand, the learning and teaching processes are determined by the existing values of society, and ecological factors (Hofstede 2001) such as historical background, geographical position of the country, ethnic composition, etc. The organization of the learning and teaching processes is greatly influenced by cultural differences. Geert Hofstede, a Dutch social psychologist, conducted studies on modern cultures and defined four primary cultural dimensions, which despite much criticism (e.g.: Baskervilleon 2013, Jones 2007, Boski 2010, Strelau and Doliński 2008) provide a comprehensive and widely applied models of the cultural differences in different parts of the world. Moreover, he described the role of cultural differences in learning and teaching process, which is pertinent to this article. In his work, Hofstede refers to some perplexities that may arise when teacher and students come from various cultural backgrounds (Hofstede 1986). The indicators of the four cultural dimensions (The Power Distance, the Uncertainty Avoidance, Individualism versus Collectivism Dimension, Masculinity versus Femininity Dimension) for Teacher-Student interactions are used for the analysis of the national curricula in order to study the way Polish and Ukrainian educational laws define the learning and teaching 
processes and Teacher-Student relations. Additionally, the goal of this article is to study the correlation between the national curricula and Polish and Ukrainian cultural differences in their teaching and learning processes, as well as their management and organization styles.

To provide a comprehensive analysis, four valid documents were studied - the Regulation of the Minister of National Education of Poland of 14 February 2017 on the core curriculum for pre-school education and the core curriculum for general education in primary schools, and three Ukrainian documents that regulate the educational process in the primary and secondary schools, The State Standard of Primary Education in Ukraine, Decree from November 23rd, 2011, The State Standard of Basic and General Secondary Education in Ukraine, Decree from April 20th, 2011, The Concept of the "New Ukrainian School".

\section{CULTURAL DIMENSIONS}

Learning and teaching processes, including teacher-student relations are determined by various factors, such as the role and social status of teachers, management and the organizational styles of schools, cultural differences, etc. Culture and values play an essential role in the functioning of the T-S dyad (Hofstede G., Hofstede G. J. and Minkov 2010). Many scientists (Myers and Tan 2002, Gutterman 2016, Kluckhohn and Strodbeck 1961, Hall 1976, Trompenaars 1993 in Wackowski and Blyznyuk 2017) tried to define factors that would allow cultural characteristics to be identified.

Hofstede defines culture as a "collective programming of the mind that distinguishes the members of one group of categories of people from another" where mind is "feeling, thinking and acting with consequences for beliefs, attitudes and skills" (Hofstede 2001: 9). Culture determines the uniqueness of a certain collectivity in the same way values and personality characterize an individual.

Differences and similarities between the cultures depend on the historical background and experience of a society. Hofstede points out several mechanisms, presented in Figure 1, that let a group preserve their own culture for following generations.

Figure 1. The "Onion Diagram”: Manifestation of Culture at Different Levels of Depth

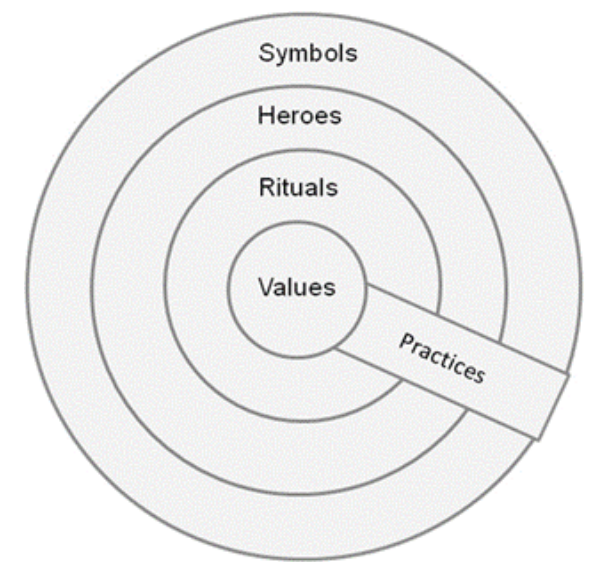

Source: Hofstede (2001). 
The value systems that are shared by most of the population are at the center of the diagram. They, on the one hand, are rooted in the certain ecological factors, such as geography, history, demography, technology, etc., while on the other, specify the structure and functioning of the institutions, e.g. family patterns and educational systems, religion, etc., in a society. The established institutions support and reinforce the social norms and values of its community. Moreover, they rarely change or influence the norms within a relatively close society.

The outer layer of the diagram represents symbols, characterized by words, gesture and pictures that carry some meaning recognized in the culture. The following mechanism represents real or imaginary heroes who are prized and followed in the group. The final one is rituals, that is the activities needed to achieve goals and these are essential for individuals to be part of the culture. Practices, which connect all the mechanisms, are visible to outsiders and have considerable meaning to the insiders of the culture (Hofstede 2001).

These mechanisms and practices are necessary for preserving a society's history and identity, as well as to passing the culture on to posterity. Hofstede (1986) analyzes cultures through four primary dimensions: power distance, uncertainty avoidance, individual versus collectivist cultures, femininity versus masculinity. Power distance characterizes the level of the inequality which less powerful individuals tolerate and consider its normality. Uncertainty Avoidance characterizes the extent to which people from one culture are made nervous because of an unpredicted, unstructured or unclear situation that requires other that traditional solutions. Individualist cultures assume that a person minds own (and his/her immediate family) interests and matters, while in the collectivist cultures a person belongs to the integrated groups and protects their interests. Masculinity and femininity within a culture defines the social roles attributed to men and women. The masculine cultures strive to set a clear distinction between man, being ambitious, competitive, big and strong, and woman, being small and weak (Hofstede 1986).

These dimensions were brought up after the study conducted in more than 50 countries in 3 regions, the main aim of which was to gauge the impact of the differences in national culture and management. The researchers used a survey (Values Survey Module) to run the study (Hofstede 1980). As some Central European countries didn't take part in the main research, Kolman et al. (2003) conducted the supplementary one including the Czech Republic, Hungary, Poland and Slovakia. The Netherlands was surveyed to conduct a comparison. As Ukraine was not surveyed in the primary research, the scores were estimated comparing Ukraine to the rest of the European participating countries. Prykarpatska (2008) provided the estimated scores of the cultural dimensions in Ukraine basing on the comparison of the cultural dimensions ranking list for European nations composed by Mikułowski-Pomorski (Mikułowski-Pomorski 2006 in Prykarpatska 2008) [The results can be seen in the Appendix 1]. The scores are largely corresponding to the ones published on the webpage https://www.hofstede-insights. com/. The scores are rarely updated because the dimensions of the culture are changing very slowly, from generation to generation (Hofstede 2019).

As a result of the following studies Hofstede (Hofstede G., Hofstede G. J. and Minkov 
2010) added two more dimensions Long-Short Term Orientation, which defines the plans for future, and Indulgence- Restraint, that shows "the extent to which people try to control their desires and impulses, based on the way they were raised" (Hofstede Insights 2019).

Four primary dimensions, viz Power Distance, Individualism versus Collectivism, Femininity versus Masculinity and Uncertainty Avoidance, which Hofstede refer to the learning and teaching processes, are used in this paper and make the background for the critical discourse analysis of the national documents in Poland and Ukraine.

\section{THE IMPACT OF CULTURAL DIFFERENCE ON EDUCATIONAL PROCESS IN PO- LAND AND UKRAINE}

This article analyzes the characteristics of the educational process defined by the national curricula through the Hofstede's 4-D model of cultural dimensions. The two countries were chosen for their numerous similarities: Poland and Ukraine are neighboring states with a common border of $535 \mathrm{~km}$; both countries were influenced by the communist regime (Poland till 1989, Ukraine till 1991); the end of the communist regime caused many social, cultural, economic, educational changes in both states. Moreover, the Education expenditure GDP in Poland and Ukraine in recent years has been similar with 5,0\% [1] and 5,1\% [2] respectively. Despite the geographical and historical similarities, Polish and Ukrainian cultures differ a lot. The figure bellow presents the results of the survey of cultural differences in Poland and Ukraine presented by the Hofstede Institute.

Figure 2. Cultural Differences (in \%) Between Poland (blue colour) and Ukraine (violet colour) (estimated) by Hofstede Insights 2019

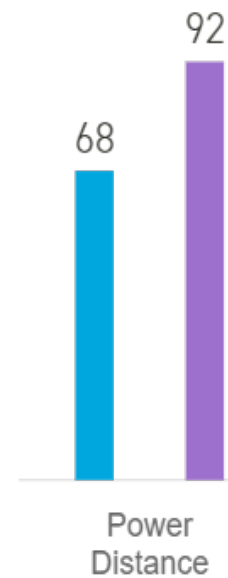

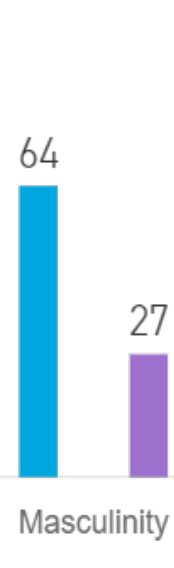

Individualism

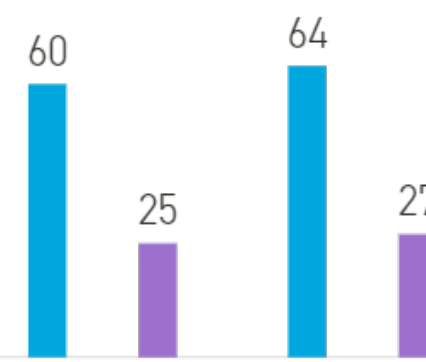

Masculinity

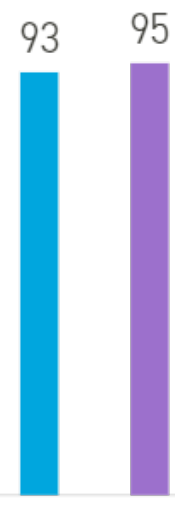

Uncertainty Avoidance

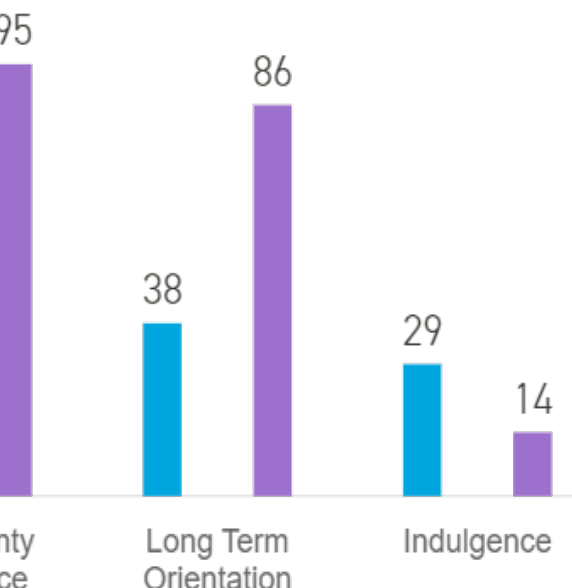

Orientation

\section{4}

dulgence

Source: Self-generated, based on Hofstede 2019. 
According to the survey results, Poland revealed a relatively large Power Distance in comparison to Western Countries, though the lowest indicator among the four Central European countries. At a score of 62 in Kolman's et al. (2003) and 68 in Hofstede Insights, Poland is a hierarchical country. It indicates that "[Polish] people accept a hierarchical order in which everybody has a place, and which needs no further justification" (Hofstede Insights 2019). Poles used to have good relations with their superiors, who tended to have an autocratic management style (Kolman 2003). Poland still maintains authoritative, less democratic and participative, business relations than the Western European countries (Odrowąż-Coates 2017).

Ukraine scored 92 on this dimension. Its historical background of the XX century strongly influenced the centralization of power and authorities, where the power holders put great emphasis on social status and national symbols (Hofstede Insights 2019). Corruption Percentage Index (CPI) is among the indicators of Power Distance. In 2016, the Index for Ukraine was 131 and 29 for Poland (maximum 176). CPI in a way explains the 92 and 62 Power Distance Dimension scores in the Ukraine and Poland (Wackowski and Blyznyuk 2017, Woldan 2009). Large Power Distance, hierarchical order and autocratic attitude may increase the fear and lack of trust among employees (Baranowski and Odrowąż-Coates 2018; Odrowąż-Coates 2017). The hierarchical position of teachers at school also cause fear and distrust among pupils. The table below presents the indicators of the level of Power Distance in educational institutions.

Table 1. Differences in Teacher/Student Interactions related to The Power Distance Dimension (Hofstede 1986: 313)

\begin{tabular}{|c|c|}
\hline SMALL POWER DISTANCE SOCIETIES & LARGE POWER DISTANCE SOCIETIES \\
\hline $\begin{array}{l}\text { - knowledge can be obtained from any compe- } \\
\text { tence person or source } \\
\text { - student-centered education } \\
\text { - the teacher respects the students' independence } \\
\text { - the teacher gives students the chance to start a } \\
\text { conversation } \\
\text { - students can contradict the teacher } \\
\text { - teachers are treated equally outside the school } \\
\text { - parents support students' side } \\
\text { - young teachers are more liked by the students } \\
\text { - the teacher expects students to find their own } \\
\text { paths }\end{array}$ & $\begin{array}{l}\text { - teacher is the only reliable source of knowl- } \\
\text { edge and a "guru” to the students } \\
\text { - teacher-centered education } \\
\text { - the teacher is the one who set the paths and } \\
\text { starts communication } \\
\text { - the teacher is not publicly criticized } \\
\text { - Students speak when the teacher invites } \\
\text { - the learning effectiveness depends on the } \\
\text { teachers' excellence } \\
\text { - parents rather support the teachers' side } \\
\text { - students show the teacher respect outside } \\
\text { school } \\
\text { - older teachers are more respected than young } \\
\text { ones } \\
\text { - students expect teacher to outline the paths }\end{array}$ \\
\hline
\end{tabular}

Source: Self-generated, based on Hofstede 1986. 
On the Individualism dimension Poland scored 60. This means that Poland is average among the Central European countries, but more collectivistic than Western European countries, though much more individualistic than Asian countries. Ukraine, on the contrary, scored 25 on this dimension, that demonstrates the influence of being a part of the Soviet Union for quite a long time. The main postulate of the USSR was to create the community and perceive an individual as an integrative part of it (Wackowski and Blyznyuk 2017, Hofstede Insights 2019). In the collectivist countries, employees are more likely to cooperate than to work individually. Additionally, relations in business are very important and must be built carefully. Poland, however, has a unique culture with a high level of PD and high level of IDV, that requires lots of skill in managing the companies where "the manager is advised to establish a second "level" of communication, having personal contact with everybody in the structure, giving the impression that "everybody is important" in the organization, although unequal" (Hofstede Insight 2019).

In terms of school Individualism-Collectivism, these cultures are illustrated in the learning programs and materials, which are developed to educate and raise some values, and perceive students either as an individual or a part of the group. The table below shows level indicators of Individualism and Collectivism in educational institutions.

Poland has a highly masculine culture with a score of 64, where business is driven by competition, achievement and success. In masculine cultures the main motivation for employees is a desire to be the best and admired (Kolman et al. 2003, Hofstede Insight 2019). Whereas, according to the study, Ukraine is rather a feminine country with a masculine score of 27 . Feminine culture is characterized by modest behavior, great care for others and the importance of relations (Wackowski and Blyznyuk 2017).

A low score at a masculine might be related to the large Power Distance in Ukraine, where the superiors show their dominant behavior, whilst is not appreciated among the peers (Hofstede Insights 2019). This dimension illustrates the way the school specifies the reward and punishment systems, along with the purpose of the education. 
Table 2. Differences in Teacher/Student and Student/Student Interaction Related to the Individualism versus Collectivism Dimension (Hofstede 1986: 312)

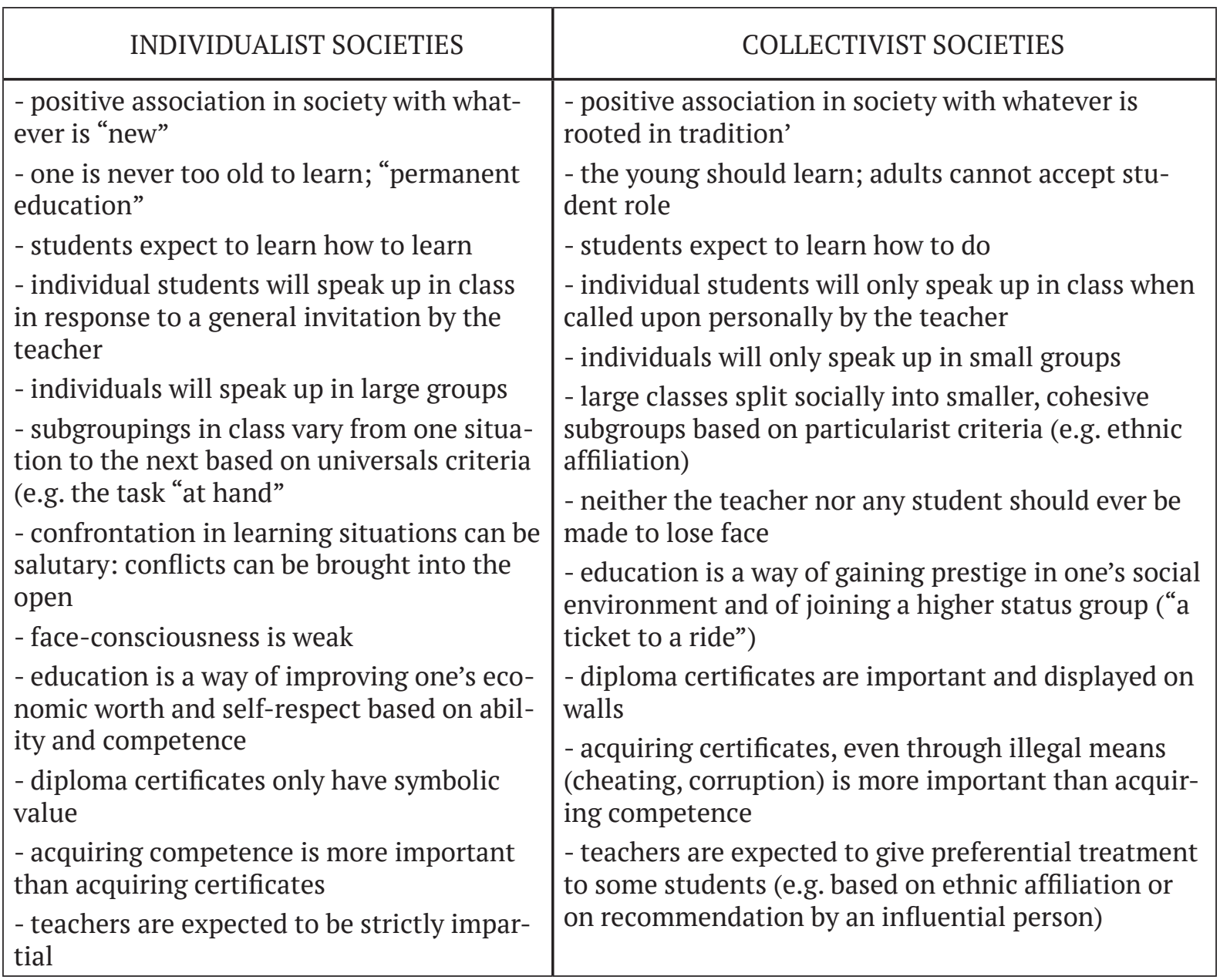

Source: Self-generated, based on Hofstede 1986.

The table 3 displays the indicators of the Feminine and Masculine types of running the educational institutions.

Poland scored 93 at the Uncertainty Avoidance (UA) dimension, which is relatively high, while Ukraine 95 respectively. A high Uncertainty Avoidance indicates rigid beliefs and practices, where citizens are against sudden and unexpected change, have a strong attachment to established rules and norms and used to plan the nearest future (Hofstede Insight 2019). A high level of Uncertainty Avoidance is also characterized by the rigid hierarchical management structure and conservative rules and procedures in business relations (Wackowski and Blyznyuk 2017). A UA level directly outlines the management style and structure of the institutions, for example schools. It also determines the learning programs and the approach to teaching styles. The table below presents the indicators of Uncertainty Avoidance typical for educational institutions. 
Table 3. Differences in Teacher/Student and Student/Student Interaction Related to the Masculinity versus Femininity Dimension (Hofstede 1986: 315)

\begin{tabular}{|l|l|}
\hline \multicolumn{1}{|c|}{ FEMININE SOCIETIES } & \multicolumn{1}{|c|}{ MASCULINE SOCIETIES } \\
\hline - teachers use average student as the norm & - teachers use best students as the norm \\
- system rewards students' social adaptation & - system rewards students' academic performance \\
- students admire friendliness in teachers & - students admire brilliance in teachers \\
- corporal punishment severely rejected & $\begin{array}{l}\text { - corporal punishment occasionally considered } \\
\text { salutary } \\
\text { - male students may choose traditionally femi- } \\
\text { nine academic subjects } \\
\text { - students choose academic subjects in view of } \\
\text { intrinsic interest }\end{array}$ \\
\hline
\end{tabular}

Source: Self-generated, based on Hofstede 1986.

Table 4. Differences in teacher/student interactions related to the uncertainty avoidance dimension (Hofstede 1986: 314)

\begin{tabular}{|c|c|}
\hline $\begin{array}{l}\text { WEAK UNCERTAINTY AVOIDANCE } \\
\text { SOCIETIES }\end{array}$ & $\begin{array}{l}\text { STRONG UNCERTAINTY AVOIDANCE } \\
\text { SOCIETIES }\end{array}$ \\
\hline $\begin{array}{l}\text { - students feel comfortable in unstructured } \\
\text { learning situations: vague objectives, broad }\end{array}$ & $\begin{array}{l}\text { - students feel comfortable in structured learning } \\
\text { situations: precise objectives, detailed assignments, }\end{array}$ \\
\hline - teachers are allowed to say “I don’t know” & - teachers are expected to have all the answers \\
\hline - a good teacher uses plain language & - a good teacher uses academic language \\
\hline $\begin{array}{l}\text { - students are rewarded for innovative ap- } \\
\text { proaches to problem solving }\end{array}$ & $\begin{array}{l}\text { - students are rewarded for accuracy in problem } \\
\text { solving }\end{array}$ \\
\hline $\begin{array}{l}\text { - teachers are expected to suppress emotions } \\
\text { (as are students) }\end{array}$ & $\begin{array}{l}\text { - teachers are allowed to behave emotionally (as are } \\
\text { students) }\end{array}$ \\
\hline $\begin{array}{l}\text { - teachers interpret intellectual disagreement } \\
\text { as a stimulating exercise }\end{array}$ & $\begin{array}{l}\text { - teachers interpret intellectual disagreement as } \\
\text { personal disloyalty }\end{array}$ \\
\hline - teachers seek parents' ideas & $\begin{array}{l}\text { - teachers consider themselves experts who cannot } \\
\text { learn anything from lay parents-and parents agree }\end{array}$ \\
\hline
\end{tabular}

Source: Self-generated, based on Hofstede 1986. 
The aforementioned cultural differences with the indicators listed state the basis for the analysis of the national curricula of Poland and Ukraine.

\section{RESEARCH DESIGN}

The purpose of our article was to show whether and to what extent the individual indicators of the cultural dimensions described by Hofstede are "reflected" in Polish and Ukrainian laws which define the learning and teaching processes, and teacher-student relations. The legal documents we have analyzed function as national curricula. Let's remember that the additional goal of this article is to study the correlation between the national curricula and the cultural differences of Polish and Ukrainian cultures in teaching and learning processes, as well as their management and organizational styles.

In Polish education law, the applicable teaching content and skills that must be included in the curriculum are presented in the Regulation of the Minister of National Education of 14 February 2017 which contains the core curriculum for pre-school education and the core curriculum for general education in primary schools. This is the main document that organizes the learning process in Polish schools. There is no exact equivalent of the Polish core curriculum in Ukraine, but there are other national documents regulating the learning and teaching process. They are: The State Standard of Primary Education in Ukraine, Decree from November 23rd, 2011, The State Standard of Basic and General Secondary Education in Ukraine, Decree from April 20th, 2011, and The Concept of the "New Ukrainian School" from 2018. All three documents are currently in force and regulate the educational process in primary and secondary schools in Ukraine. The concept of the "New Ukrainian School" has been implemented since the $2017 / 2018$ school year, firstly for the first graders, and is expected to supersede the other two Decrees by 2021. The listed documents in their original languages - Polish and Ukrainian - were the subject of our analysis. We chose critical discourse analysis as the research method. We remained aware that there are two approaches to discourse analysis popularized among researchers from around the world: the socalled French concept of discourse (Foucault, Habermas, Ducrot) and the Anglo-Saxon concept of discourse (van Dijk). According to the French school, linguistic layers of the text are the primary subject of analysis. According to the Anglo-Saxon school, discourse analysis falls within the socio-cultural current and its purpose is to recognize the social and political structure, as well as to identify current social problems that are reflected in the discourse (Grzymała-Kazłowska 2004).

Critical discourse analysis has now grown into one of the most popular interdisciplinary research perspectives. It covers a rich and diverse range of methods and positions (Ostrowicka 2014), and, for several reasons, proved to be the suitable for our studies. First, we treat national curricula as specific statements on education that are communicatory in character yet contain elements of persuasion (Śliwerski 2009). Secondly, specific indicators of cultural dimensions which appear in national curricula are an expression of what from the outset is considered important in educational reality. (Generally speaking, "the creators of national curricula have decided what is 
important"). It can also be assumed as that the contents of national curricula are conveyors of belief systems and values, and even of presumed visions of a certain social order. The belief system and values in question have been analyzed by us using Hofstede's cultural dimensions: power distance, uncertainty avoidance, individual versus collectivist cultures, femininity versus masculinity. We want to discover how visions from national curricula coincide with reality. Thirdly, we want to show the manipulative role of national curricula. The documents which we will analyse oblige - at least formally - Polish and Ukrainian teachers and students to understand learning and teaching, and the organization of these processes in accordance with national curricula. Critical discourse analysis will allow us to take a "new" look at the analyzed documents. We will see which elements of Hofstede's cultural analysis are particularly strengthened and which are not found in the analyzed documents. Fourthly, we assume that as researchers we are not axiologically neutral. Each of us will analyze documents from our country of origin. We realize that we are representatives of different cultures and identify with different Hofstede's dimension indicators. As reflective researchers, however, we are aware of this and try to make it an asset, not a disadvantage (Bourdieu and Wacquant 2004; Giddens 1993)

Most often, critical discourse analysis consists of three stages. These are: 1) analysis of the text that is the subject of the research, 2) analysis of discursive social processes involving the analysis of the reception and interpretation of text by people, 3) research on the impact of discourse, i.e. reflecting on discourse as a key factor in the construction of social life (Darłowicz 2016). We will briefly touch on the first two stages because of the limited volume of our text. Given the objectives of our article, we focus primarily on the third stage.

\section{RESULTS OF RESEARCH - NATIONAL CURRICULA SEEN THROUGH THE HOF- STEDE'S 4-D MODEL OF CULTURAL DIMENSIONS}

Most definitions of culture contain a material and a spiritual aspect. Culture is defined by Hofstede at al. (2010) as a collective mind programming that distinguishes members of one group or category from members of another. National cultures are defined as collective mind programming resulting from growing up in a particular country. Culture contains specific dimensions (described as Hofstede's 4-D model) that are subject to observation and measurement.

Let's look at the contents of core curricula through the prism of Power Distance. In both Ukrainian and Polish core curricula there is a clear advantage to small power distance. One of the indicators of this dimension is societies-knowledge can be obtained from any competence person or source. The ability to independently search for information, critically evaluate it and form independent judgments is emphasized. For example: a student is to: "critically analyze and use information from various sources" (Regulation of the Minister 2017: 12), "formulate judgments on selected social problems of the modern world" (Regulation of the Minister 2017: 109); "student's ability to use information and communication technologies and other means for performing personal and socially important tasks" (The State Standard of Primary Education in 
Ukraine 2011: 2). However, we did not notice a single entry affirming that the Teacher is the only reliable source of knowledge and a "guru" for the students. Polish and Ukrainian national curricula entries support student-centered education. A personalistic concept of education manifests itself, for example, in the "ability to express one's own expectations and social needs" (Regulation of the Minister ...: 32), "encouraging students to self-assess their own work" (Regulation of the Minister 2017: 81). "The most nurturing teaching methods are those that mobilize the student, enabling him to build knowledge by himself" (Regulation of the Minister 2017: 129). In Ukraine: “there isn't any administrative control that limits pedagogical creativity, children's active participation in the educational process, interests and experience-oriented education" (The State Standard of Primary Education in Ukraine 2011: 18). Students are to have the opportunity to experiment, work with projects, their cognitive activity is to be stimulated (Regulation of the Minister 2017: 150). Education -applied to the subject of preparation for family life - concerns the ability to adopt an integral vision of an individual as well as the choice and implementation of values serving personal development (Regulation of the Minister ...: 197). Despite the general attitude towards student-centered education, there are manifestations of teacher-centered education in the Polish national core curriculum. These are noticeable at the education planning level - those responsible for this sphere are the teachers, who 'by organizing classes plan the education process (Regulation of the Minister 2017: 54). However, teachers are not the ones who set the paths and start communication. On the contrary, in both national core curricula we find many regulations supporting respecting students' independence by teachers. Let's give some examples. Teachers are obliged to: "support the student in identifying his own predispositions and determining the path of further education" (Regulation of the Minister 2017: 11), "encouraging < students> to organized and conscious self-education based on the ability to prepare their own workshop (Regulation of the Minister 2017: 11).

Ukrainian curriculum states: „distributed leadership (productivity, making a choice and responsibility for it)"; also "[the educational institution] needs to ensure freedom and children's rights in all aspects, (The State Standard of Primary Education in Ukraine 2011: 17,19).

Education, therefore, has as its task: "to awaken and develop a student's reflexivity and axiological sensitivity and to nurture an attitude of respect, openness, cooperation and responsibility" (Regulation of the Minister 2017: 30). Whilst in the Ukrainian curriculum "[teachers] need to make the educational environment as a bright element of childhood" and "[a teacher] needs to take into account the individual abilities and skills of every pupil" (The State Standard of Primary Education in Ukraine 2011: 18, 19). Polish and Ukrainian national core curricula contain many records proving that a teacher allows students to start a conversation and choose a path. However, there is no record that a teacher cannot be publicly criticized, and that student can only speak when the teacher invites them to. We discovered indications of giving the students the opportunity to choose their own education path and the unfettered voice in the following narratives: "encouraging organized and conscious self-education based on the skill of preparing their own workshop" (Regulation of the Minister 2017: 11), "the student 
attains the need and the skill of independent, reflective, logical, critical and creative thinking "(Regulation of the Minister 2017: 33)," the student... agrees with or disputes other people's opinions, substantively justifying his own opinion (Regulation of the Minister 2017: 68), "the student 1) recognizes his/her own needs and the needs of others; 2) plans further education, taking into account his/her skills and interests; ... 4) presents his/her own rights and obligations "(Regulation of the Minister 2017: 104). Additionally, Ukrainian documents inform of „ensuring the possibility to make choices and independent decisions while realizing their consequences" (Bibik 2018: 45); "provide time and opportunities for critical thinking; appreciate this, allowing children to think freely" (Bibik 2018: 62).

Some of the indicators listed by Hofstede on both the small and large power distance were not identified by us in the Polish and Ukrainian national core curricula. These were indicators that the parents were either for or against the teacher and related to the importance of the teacher's age - neither are young teachers more liked by the students, nor are older teachers more respected than the young ones.

Our analyses of the Polish and Ukrainian core curriculum from a small-large power distance perspective in the context of research on national cultures allow us to draw some conclusions. Firstly, the hierarchical nature of Polish society is reflected in the Polish core curriculum to a negligible (practically imperceptible) degree. Similarly though not so clearly - it is presented in the Ukrainian core curriculum, with greater attention to child-centered education with respect to children's rights, voice and choice. Secondly, teachers and children are treated as partners. "[The educational process] is realized by the joint participation of teachers and students, teachers and parents, which involves understanding, shared interests and aspirations for the personal development of students" (Bibik 2018: 17). Moreover, the partnership principals are defined as: "respect, goodwill and positive attitude, trust, dialog, cooperation, shared leadership (pro-activeness), and social partnership (equality of parties, voluntary commitment, and an obligation to fulfill agreements) (Bibik 2018:17).

Let's remember that Polish culture, according to Hofstede research, is characterized by a fairly high degree of individualism and the Ukrainian culture is more collective. Is this result reflected in the core curricula we analyzed and if so, to what degree? What do the Polish and Ukrainian core curricula say about interpersonal relations; social networks; sources of identification - "I", "we"?

The authors of the Polish core curriculum repeatedly refer to social collectivism and try to show the importance of tradition. Specific and easily identifiable examples are: 'Education and upbringing in a primary school are conducive to developing civic, patriotic and social attitudes of students.' The school's task is to strengthen the sense of national identity, attachment to national history and traditions" (Regulation of the Minister 2017: 14). “In the implemented didactic and educational process, the school undertakes activities related to places important for national memory, forms of commemorating figures and events from the past, the most important national holidays and state symbols” (Regulation of the Minister 2017: 15), “The awakening of a sense of love for the homeland through respect and attachment to the tradition and history of one's nation and its achievements, culture and mother tongue is shaped during the 
implementation of the history subject" (Regulation of the Minister 2017: 22), “The teacher's task ... is above all ... to develop a sense of national identity and respect for tradition" (Regulation of the Minister 2017: 70) and many others. A similar position is taken by the Ukrainian educational system, noting that it's important "to be able to cooperate with various partners in groups and pairs, play different roles and functions within a group" (The State Standard of Primary Education in Ukraine 2011: 2).

In the light of the analyzed documents, positive association in society with whatever is "new" is also noticeable, but to a lesser extent than traditionalism, Contents of the core curriculum relating to modernity are limited to the "technical" side of education and relate to the latest technologies, e.g. "The student ... distinguishes between modern forms of messaging (e.g. e-mail, SMS) and uses them properly, observing the rules of language etiquette" (Regulation of the Minister 2017: 64), "Programming and solving problems using a computer and other digital devices: arranging and programming algorithms, organizing, searching and sharing information, using computer applications" (Regulation of the Minister 2017: 175). Meanwhile similar content can be found in the Ukrainian curriculum: "[pupil can] search the necessary information using search engines and expert systems, including the Internet” (The State Standard of Primary Education in Ukraine 2011: 13). At one point of the core curriculum, we noticed a provision about permanent education, namely: "The student plans further education, taking into account his own interests, abilities and skills as well as advice of other people and the situation on the labor market" (Regulation of the Minister 2017: 105). In the Ukrainian curriculum, lifelong learning makes up one of the key skills of the pupils: "there should be provided the possibility for individual development of pupils, who will be able to self-realize and participate in the life of a democratic, social, legislative and civil society of the today's diverse world with a help of the gained skills and knowledge" (The State Standard of Primary Education in Ukraine 2011: 8).

An indicator of Hofstede's collectivism is the following category - students expect to learn how to do, and of individualism the following category - students expect to learn how to learn. Both are clearly displayed in the Polish core curriculum and it is difficult to discern which is the more predominant. Clearly the authors of the core considered both categories equally important. The following fragments may be taken as indicators of learn how to do: "To understand the essence of life science, practical knowledge is also indispensable" (Regulation of the Minister 2017: 25), "Therefore, they should learn the basic methods of IT so that they can use them in the future in practical situations in various fields" (Regulation of the Minister 2017: 27), “The student attains ... the ability to ask questions, perceive problems, collect information needed to solve them, plan and organize the activity, as well as solve problems" (Regulation of the Minister 2017: 33 ), "It is necessary to implement the content of teaching in such a way that students understand the usefulness of individual issues in the everyday life of a human being - a member of individual social groups and communities (Regulation of the Minister 2017: 109). The how to learn category was noticed by us in the following - selected - fragments of the Polish core curriculum: "Even the best school will not teach everything. However, it will provide tools to expand knowledge independently, while maintaining the necessary criticism and ensuring the reliability 
of the communication" (Regulation of the Minister 2017: 22), "The student ... uses acquired skills to solve problems and explore the world, taking care of (their) own development and creating individual learning strategies" (Regulation of the Minister 2017: 36), "Developing skills of independent information access, selection, synthesis and evaluation. Developing habits of systematic learning and of organizing acquired knowledge and deepening it" (Regulation of the Minister 2017: 60). The Ukrainian educational program also tends to teach pupils how to learn: "[pupil] has an ability to learn - prove their own opinion and shared thoughts” (Bibik 2018: 17).

In the Polish core curriculum, we found an entry indicating collectivism, indicated by individual students will only speak up in class when called upon personally by the teacher. This entry read: "The student ... listens and waits his turn, controls the urge to speak suddenly (Regulation of the Minister 2017: 34).

The Polish core curriculum contains individual entries which we have identified as manifestations of individualism, but which are difficult to relate directly to indicators distinguished by Hofstede, e.g. "The project method assumes a significant independence and responsibility of participants, which creates conditions for students to individually manage the learning process" (Regulation of the Minister 2017: 14) or "The school and individual teachers undertake actions aimed at individualized support for the development of each student, according to his needs and abilities" (Regulation of the Minister 2017: 13).

Ukraine is defined as a collectivist country, whereas the New Ukrainian School, which provides the foundation for a new Standard of the Primary and Secondary Education, presents proof of both dimensions - individualism and collectivism. It's said that it's important, on the one hand, to "build skills of collective work and cooperation" (The State Standard of Primary Education in Ukraine 2011: 2), while on the other, "[develop] critical thinking: pupils learn to question, doubt and assess opinions, which are different or similar to theirs" (Bibik 2018: 49). The new program also promotes teachers' impartial treatment, noting: "fairness and impartial treatment ... a teacher and children perceive the contribution of every child equally, with kindness and respect regardless of their abilities, social background or gender" (Bibik 2018: 49).

Another dimension of Hofstede's 4-D model of cultural differences among societies is determined by masculinity at one extreme and femininity at the other. In fact, we didn't find any references to masculinity in either of the core curricula. The exception is the provision in the Polish core, testifying that students admire brilliance in teachers, which reads: "The student: listens carefully to the teacher's statements ... shows respect to the speaking person" (Regulation of the Minister 2017: 34). There are references to femininity in the Polish and Ukrainian cores, but in trace amounts. Examples from the Polish core curriculum are: the school ensuring safe conditions and a friendly learning atmosphere (Regulation of the Minister 2017: 11) and "introducing students to the world of values, including dedication, cooperation, solidarity and altruism" (Regulation of the Minister 2017: 11).

The Ukrainian curriculum stresses the necessity of taking into account the abilities and skills of every child: "...refusal to focus on the educational achievements of the average student and compulsory consideration of the interests of each child" 
(Bibik 2018: 19). The new Ukrainian Standard of Education is based on the following principals that qualify the country to the feminine dimension group: "Recognizing that every child is talented. Ensuring equal access to education, prohibiting all forms of discrimination. Separation of children based on pre-selection at individual, group and institutional levels will not be allowed" (Bibik 2018: 22). Moreover, the curriculum prohibits psychological or corporal punishment by stating "Security. Creating an atmosphere of trust and mutual respect. Making the school a safe place where there is no violence and harassment" (Bibik 2018:23). Additionally, the core curriculum gives advice to the teachers about how to choose and realize the topic of the lessons, taking into the account every child's interests. It is said that "Additional training sessions for assistants may be held throughout the year, depending on the needs and interests of the assistants ...Make a list of tasks for each assistant, including their interests in the skills and needs of the teacher" (Bibik 2018: 112).

The categories of femininity and masculinity are associated with consent or lack of it to show concern for others, friendly or competitive relationships; valuing or not material success and progress, and clearly divided into male and female roles. Both countries promote the feminine approach to the learning and teaching processes, highlighting the importance of perceiving each child as an individual with their own needs, ideas, and opinions; free of violence and corporal punishment at school.

Societies with weak uncertainty avoidance have few rights and principles. If existing regulations are often unobserved, they should be changed. These societies are tolerant and friendly to young people. Societies with strong uncertainty avoidance abide by many detailed laws and principles. Conservatism, law, order and a hostile attitude to young people dominate. It is easy to conclude that these societies are intolerant and marked by religious, ideological and political fundamentalism. The discovery of manifestations of both week uncertainty avoidance societies and strong uncertainty avoidance societies in national core curricula was a major research challenge.

In the Polish national core curriculum, there is relatively little content that can be related to the analyzed dimension, and if it is present then it is rather on the week and not strong avoidance societies' side. Interestingly, according to Hofstede, the fact that teachers are allowed to behave emotionally (as are the students) is an indicator of strong uncertainty avoidance. References to the emotional aspect of education and upbringing are revealed in the selected quoted narratives: "The school's tasks include ... understanding of emotions, own feelings and those of others, conducive to maintaining mental, physical and social health" (Regulation of the Minister 2017: 18), "Emotionality is an important factor shaping the development of the student and determining the perception of themselves, other people and the world" (Regulation of the Minister 2017: 21), "The student achieves ... the ability to realize the feelings experienced by other people while trying to understand why they occur, as well as differentiating forms of their expression depending on age" (Regulation of the Minister 2017: 32) "The student uses the names of emotions and feelings to describe his own experiences and the experiences of other people in the context of various moral experiences; uses these concepts to characterize the experiences, actions and attitudes of the characters in novels, stories, films, theater performances and computer games" (Regulation of 
the Minister 2017: 203). A closer look at the fragments concerning feelings and the expression of emotions, recorded in the Polish core curriculum raises some doubts as to the assignment of these descriptions to the category of the strong avoidance societies. In social practice, the free expression of emotions is after all an expression of tolerance and friendship in interpersonal contacts, i.e. it is equivalent to less avoidance societies. Undoubtedly, this very dimension, i.e. of less avoidance societies - is reinforced by the indicators of the category: students are rewarded for innovative approaches to problem solving written in the Polish national curriculum. Examples: "General education in primary school aims to: ... 4) develop competences such as creativity, innovation and entrepreneurship; 5) develop the skills of critical and logical thinking, reasoning, arguing and inferring" (Regulation of the Minister 2017: 11), "The most important skills developed as part of a general education in a primary school are: ... 4) creative problem solving in various fields with the conscious use of methods and tools derived from computer science" (Regulation of the Minister 2017: 12), "The subject of physics is above all an opportunity to constructively verify students' views and a time in which to build the foundations of scientific thinking - asking questions and looking for structured answers" (Regulation of the Minister 2017: 159). The Polish core curriculum contains individual entries that can be indirectly referred to the category - teachers interpret intellectual disagreement as a stimulating exercise. These read as follows: "Teachers ... should aim for students to shape within themselves an attitude of dialogue, the ability to listen to others and understand their views (Regulation of the Minister 2017: 29-30). We also have an indirect reference to the category - teachers seek parents' ideas. "Raising a younger generation is the task of the family and the school, which in its activities must take into account the will of the parents" (Regulation of the Minister 2017: 15). The same category also appears in the description of the subject of preparation for family life - "The school's tasks in the field of preparation for family life include in particular: supporting the educational role of the family "(Regulation of the Minister 2017: 201). The Polish core of the programs does not contain a single record stating that teachers interpret intellectual disagreement as personal disloyalty nor that teachers consider themselves experts who cannot learn anything from lay parents - and parents agree.

In the comparison, Ukrainian curriculum promotes the ideas of open-minded teaching styles, that give more freedom and accounts for everyone's needs. The school day is planned, and the lessons are conducted based on chosen topics, as the curriculum points out all the topics that should be covered at the primary and secondary school. The new core curriculum, however, suggests a more flexible approach towards lesson plans. It is mentioned that "the educational tasks and time for their [primary pupils] implementation depend on the individual characteristics of the students ... training should be organized through activities, by means of play both in the classroom and beyond" (Bibik 2018: 20, Nychkalo 2017), what's more "It is recommended that 20\% of the planned study time must be reserved to enable students to meet their educational needs, balance their achievements, develop transversal skills, etc." (Bibik 2018:25). It is also mentioned that teachers are allowed to say "I don't know, that characterizes the weak uncertainty avoidance cultures, "[teachers] should be honest and admit 
their mistakes" (Bibik 2018: 45). In the category students are rewarded for innovative approaches to problem solving, the national curriculum of Ukraine says that "a creative self-expression ... critical thinking and creative thinking” (The State Standard of Primary Education in Ukraine 2011:3,8) is appreciated. In order to prove that teachers interpret intellectual disagreement as a stimulating exercise, the core curriculum of Ukraine highlights that "A child may not agree with the ideas of others, then these issues are considered in the process of free discussion. Various ideas are listened to and discussed because there is mutual trust among children" (Bibik 2018: 49). And finally, the new Ukrainian program advises teachers to seek parents' ideas and support in educational process. It is mentioned that "Teachers invite parents and other family members to join the learning process ... Teachers regularly interact with parents and other family members to increase support for children in their learning” (Bibik 2018:110).

Attempting to summarize the weak - strong uncertainty avoidance dimension, we note that in the attitude of the Polish program the weak uncertainty avoidance dimension category is reinforced. Let us note, however, that the documents analyzed were quite poor in describing the behavior and attitudes of students and teachers that could directly refer to this dimension. However, based on what we have, we can say that the most important Polish documents regulating the processes of education and upbringing support student innovation - and therefore they support the young. They allow those who are subject to education to express their feelings freely and - to a limited extent - allow students disagreement understood as a stimulating exercise.

Ukrainian educational standard, with a high score of the strong uncertainty avoidance of the culture, almost completely organizes the learning process with a little share of self-study time. Though, it points to the necessity of teacher-parent cooperation and anticipates that teacher should admit own mistakes if there are so. The mentioned issues prove the new orientation the Ukrainian schools.

\section{CONCLUSIONS}

This article introduced the critical discourse analysis the Polish and Ukrainian national curricula through the prism of four cultural dimensions defined by Geert Hofstede. It was aimed to study the way both national standards of education define teacher-student relations and support/contradict the data of the cultural dimensions presented by the Hofstede Institute.

Although close geographical position and cultural and language similarities, Poland and Ukraine have divergent history, including the history of education and core curricula, and refer to different cultural dimensions. According to the data, Polish culture is more individualistic and masculine than Ukrainian one. Though, has a less power distance and similar uncertainty avoidance.

National curricula bare reciprocal objectives, on the one hand, to present and cherish the national culture and values, while on the other, to delineate the teaching/ learning process with the high standards and contemporary orientation of education. Poland and Ukraine have very different paths of educational programs and institutions, that are determined by the time of becoming independent. Poland became a 
sovereign country in 1918 and began to implement the unification of the secondary education and compulsory education in 1919 through the first educational programmes, published in 1918-1922. Since then, Polish national educational programs have come through many reforms and changes (Osiński 2010).

Meanwhile, Ukrainian educational standards were determined by the USSR policies for seventy years. The first independent Ukrainian law on education was passed in 1992, while the first concept of the national standard of education was adopted in 1996. The national curriculum of Ukraine had been developing till 2018, when the concept of New Ukrainian School, that supports contemporary educational standards of many European countries and Children's Rights, was legislated.

The history of the national curricula greatly affected the orientation of the education processes in both countries. Polish curriculum with its larger history presents greater attention to the student-centered education, that tend to provide space for individual work and development, while at the same time, respect and support pupil's rights and views.

Ukrainian recently adopted educational standards of a "New Ukrainian School” promotes child-oriented teaching/learning process to a greater extent than the previous ones. It stresses the necessity to provide time and space for self-study and self-evaluation of the students. Moreover, similarly to the Polish core curriculum, the new educational law of Ukraine reorganizes the learning process in the primary school. Education during the first three years lets pupils educate at own pace and does not anticipate any grades but description evaluation of the students' progress. This approach provides no pressure but motivation for the pupils.

Poland with its individual culture stresses individualism in the learning process of the pupils with cultivating skills of cooperation and ability to work in a group. Although Ukraine is an example of a collectivist culture, it promotes very similar approach towards the individual work and cooperation of the pupils of the primary and secondary schools.

Both Ukrainian and Polish curricula assume rather feminine approach to the teaching/learning process, despite the different result of the culture statistics from the Hofstede's study. Similarly, the two curricula foresee the low uncertainty avoidance of the educational process, that contradicts the results of the culture studies.

The aim of this article was to evaluate at what degree the national core curricula of Ukraine and Poland go with or contradict the indicators of the four cultural dimensions by Geert Hofstede. As a result, we can state that in the most cases the orientation of the national educational documents do not reinforce and prove the results of the cultural studies.

We would like to stress that the presented analysis concerns the study of the national documents, but not the factual situation of the teacher/learning process and teacher-student relations in Polish and Ukrainian school. In order to verify whether the actual educational process in the schools uphold the orientation of the core curricula, a distinct study should be provided. 


\section{NOTES}

[1] Monitor edukacji i kształcenia. Retrieved September 20, 2019 (https://ec.europa.eu/ education/sites/education/files/document-library-docs/et-monitor-report-2018-poland_pl.pdf).

[2] Ukraine-Government Education Expenditure. Retrieved September 20, 2019 (https://countryeconomy.com/government/expenditure/education/ukraine).

FUNDING: This research was funded by the UNESCO/Janusz Korczak Chair fellowship 2019 obtained through the Polish Commission for UNESCO

CONFLICT OF INTEREST: The authors declare no conflict of interest.

\section{REFERENCES}

Baranowski, Mariusz and Anna Odrowaz-Coates. 2018. “Critical Thinking - Tightening the Link Between Business and Education.” Forum Oświatowe 30(2): 117-133.

Baskervilleon, Rachel. 2013. "Hofstede never studied culture.” Accounting, Organizations and Society 28 (1): 1-14.

Boski, Paweł. 2010. Kulturowe ramy zachowań społecznych. Warszawa: Wydawnictwo Naukowe PWN.

Bourdieu, Pierre and Wacquant, Loïc J. D. 2004. Science of Science and Reflexivity. Cambridge: Polity Press.

Dobrołowicz, Justyna. 2016. „Analiza dyskursu i jej zastosowanie w badaniach edukacyjnych.” Jakościowe badania pedagogiczne (1)1: 34-48.

Houellebecq, Michael. 2016. Uległość. Warszawa: W.A. B.

Giddens, Anthony. 1993. New Rules of Sociological Method: A Positive Critique of Interpretive Sociologies, 2nd ed. Cambridge: Polity Press.

Grzymała-Kazłowska, Aleksandra. 2004. „Socjologicznie zorientowana analiza dyskursu na tle współczesnych badań nad dyskursem.” Kultura i Społeczeństwo 48(1):13-34.

Hofstede, Geert. 1980. Culture's Consequences: International Differences in Work-related Values. Beverly-Hills, CA: Sage.

Hofstede, Geert. 1986. "Cultural differences in teaching and learning." International Journal of intercultural relations 10(3): 301-320.

Hofstede, Geert. 2001. Culture's Consequences: Comparing Values, Behaviors, Institutions, and Organizations Across Nations, 2nd ed. Sage: Thousand Oaks, CA.

Hofstede, Geert. 2019. Cultural dimensions. Retrieved September 26, 2019 (https:// geerthofstede.com/).

Hofstede, Geert, Jan Gert, Michael Minkov. 2010. Cultures and organizations: software of the mind: intercultural cooperation and its importance for survival. 3rd ed. New York, London: McGraw-Hill. 
Hostede, Insights. 2019. Retrieved September 20, 2019 (https://www.hofstede-insights.com/country-comparison/poland,ukraine/).

Jones, Michael. 2007. Hofstede - Culturally Questionable? paper published as Jones, M, Hofstede - Culturally questionable? Oxford Business \& Economics Conference. Oxford, UK, 24-26 June 2007.

Kolman, Ludek, Niels Noorderhaven, Geert Hofstede \& Elisabeth Dienes. 2003. "Cross-cultural differences in Central Europe." Journal of Managerial Psychology 18(1):76-88.

Law of Ukraine "On Higher Education”. 2014. In: Kyiv: Verchovna Rada News, 3738/2014, pp. 2004/ Zakon Ukrainy „Pro Wyshchu Osvitu”. 2014. Kyiv: Vidomosti verchownoji Rady, 37-38/2014, st. 2004.

Monitor edukacji i kształcenia. Retrieved September 20, 2019 (https://ec.europa. eu/education/sites/education/files/document-library-docs/et-monitor-report-2018-poland_pl.pdf).

Nychkalo, Nellya. 2017. "New Ukrainian School": The Present and the View to the Future.” Labor et Educatio (5): 89-106.

Odrowąż-Coates, Anna. 2017. "Leadership, culture, and ethics in the Polish context." The Polish Review 62(2): 87-104.

Osiński, Zbigniew. 2010. „Reformowanie polskiej edukacji historycznej w XX wieku. Kształt reform a potrzeby, zainteresowania i możliwości ucznia.” Pp. 7-44 in Szkolnictwo pijarskie w czasach minionych a współczesne problemy edukacji historycznej, edited by M. Ausz \& K. Wróbel-Lipowa. Kraków-Lublin: Wydawnictwo eSPe.

Ostrowicka, Helena. 2014. „Kategoria dyskursu w języku i w badaniach edukacyjnych - w poszukiwaniu osobliwości pedagogicznie zorientowanej analizy dyskursu." Forum Oświatowe 2(52): 47-68. Retrieved September 29, 2019 (http://forumoswiatowe.pl/index.php/czasopismo/article/view/228).

Prykarpatska, Iryna. 2008. "Why are you late?: Cross-Cultural Pragmatic Study of Complaints in American English and Ukrainian." Revista Alicantina de Estudios Inglesses 21: 50-72.

Strelau, Jan and Dariusz Doliński. 2008. Psychologia akademicka. Sopot: Gdańskie Wydawnictwo Psychologiczne.

Śliwerski, Bogusław. 2009. Współczesna myśl pedagogiczna: znaczenia, klasyfikacje, badania. Kraków: Impuls.

The State Standard of Basic and General Secondary Education in Ukraine, Decree from April $20^{\text {th }}, 2011$.

Ukraine - Government Education expenditure. Retrieved September 20, 2019 (https:// countryeconomy.com/government/expenditure/education/ukraine).

Wackowski, Kazimierz and Tetyana Blyznyuk. 2017. "Modern Ukrainian and Polish business cultures: G. Hofstede’s classification.” Ekonomichny chasopys-XXI 165 (5-6): 71-74. Retrieved September 24, 2019 (https://www.researchgate.net/publication/320388959_Modern_Ukrainian_and_Polish_business_cultures_G_Hofstede's_classification).

Woldan, Alois. 2009. “Culture Dimensions in Ukraine.” Pp. 275-293 in Ukraine on its 
Way to Europe: Interim Results of the Orange Revolution, edited by J. Besters-Dilger. Frankfurt am Main: Peter Lang AG.

\section{LEGAL ACTS}

Regulation of the Minister of National Education of Poland of 14 February 2017. In: ROZPORZĄDZENIE MINISTRA EDUKACJI NARODOWEJ1 z dnia 14 lutego 2017 r. w sprawie podstawy programowej wychowania przedszkolnego oraz podstawy programowej kształcenia ogólnego dla szkoły podstawowej, w tym dla uczniów z niepełnosprawnością intelektualną w stopniu umiarkowanym lub znacznym, kształcenia ogólnego dla branżowej szkoły I stopnia, kształcenia ogólnego dla szkoły specjalnej przysposabiającej do pracy oraz kształcenia ogólnego dla szkoły policealnej.

Bibik Advisor 2018. “New Ukrainian School: Teachers’ Advisor.” Nova ukrainska shkola: poradnyk dla wchytela, edited by N.M. Bibik. Kyiv: Litera LTD. The State Standard of Primary Education in Ukraine, Decree from November 23 ${ }^{\text {rd }}, 2011$.

\section{Appendix 1.}

Table 1. Value Dimensions for Ukraine (estimated by Prykarpatska)

\begin{tabular}{|l|l|}
\hline Dimensions & Ukraine \\
\hline Individualism & $\sim 38$ \\
\hline Power Distance & $\sim 96$ \\
\hline Masculinity & $\sim 40$ \\
\hline Uncertainty Avoidance & $\sim 93$ \\
\hline
\end{tabular}

Source: Prykarpatska 2008.

\section{BIOGRAPHICAL NOTE}

Anzhela Popyk, MA, is a Doctoral Candidate at SWPS University of Social Sciences and Humanities, Warsaw.

Anna Perkowska-Klejman, $\mathrm{PhD}$ is a pedagogue, a post-doctoral researcher of reflexivity in higher education and an associate professor at the Social Pedagogy Department at the Maria Grzegorzewska University in Warsaw, Poland.

OPEN ACCESS: This article is distributed under the terms of the Creative Commons Attribution Non-commercial License (CC BY-NC 4.0) which permits any non-commercial use, and reproduction in any medium, provided the original author(s) and source are credited. 